\title{
Editorial
}

\section{A150 anos do Grande Conflito do Prata: diversas questões, diversos olhares}

Em 30 de agosto de 1864, o governo paraguaio declarou solenemente que a intervenção militar do Império do Brasil na República do Uruguai constituiria razão de guerra, ao agredir o "equilíbrio dos estados do Prata" e seus interesses nacionais. Em 12 de outubro, um destacamento do exército imperial penetrava na República Oriental del Uruguay e assaltava a vila de Mello, sede administrativa do departamento de Cerro Largo. Em 20 de outubro, com o acordo secreto de Santa Lucia, promovido pelo almirante Tamandaré, Venâncio Flores aceita as exigências do Império do Brasil, que, em poucos meses, liquidou o governo constitucional blanco uruguaio, entronizando o ditador colorado.

O governo paraguaio encontrava-se já com os pratos praticamente rotos com os unitários portenhos que dominavam o país desde a batalha de Pavón, em 17 de setembro de 1861. O controle imperial do porto de Montevidéu punha sob sursis o comércio internacional da República do Paraguai, com graves pendências fronteiriças com o Império do Brasil. A interrupção do comércio internacional assentaria golpe, talvez mortal, à ordem lopizta, apoiada na extroversão mercantil do país, no contexto de sua independência e autonomia.

Em 12 de novembro de 1864, o governo paraguaio deteve o paquete imperial Marquês de Olinda, em viagem pelo rio Paraguai, para Corumbá, levando a bordo o novo presidente da província do Mato Grosso, coronel Frederico Carneiro de Campos, declarando a guerra ao Império na mesma ocasião. Em 14 de dezembro, partiam expedições militares paraguaias para assaltar o forte de Coimbra, no sul da província do Mato Grosso, e ocupar os territórios em litígio entre os dois países. Em 13-14 de abril de 1865, tropas daquela nação atacaram e ocuparam a vila de Corrientes. Em 10-12 de junho de 1865, uma importante coluna militar paraguaia penetrava no Rio Grande do Sul pela vila de São Borja.

Com a ofensiva paraguaia, foi assinado, a toque de caixa, em $1^{\circ}$ de maio de 1865 , o denominado Tratado da Tríplice Aliança, em Buenos Aires. Já alinhavado meses antes, em junho de 1864, em Puntas del Rosário, no Uruguai, o diploma definia as condições gerais da aliança entre a República Argentina e o Império do Brasil para imporem hegemonia compartida no

http://dx.doi.org/10.5335/hdtv.15n.2.5643 
Prata, submetendo a República do Uruguai e reduzindo o Paraguai a Estado semitributário. Nas condições da entrega do governo oriental a Venancio Flores estava o compromisso de participação subalternizada do Uruguai na aliança contra o Paraguai.

O tratado regia a direção máxima da guerra, no geral sob o comando argentino; a destituição e a reformulação do governo do Paraguai; as novas fronteiras do Império e da Argentina com aquele país; o pagamento de pesada dívida de guerra; nenhuma discussão de paz até a rendição incondicional, etc. Devido ao seu caráter despótico e ao desrespeito a hábitos e costumes internacionais, o tratado seria mantido no desconhecimento dos próprios parlamentos argentino e imperial. No Uruguai, reinava a ditadura florista.

A atabalhoada expedição ofensiva do exército paraguaio resultou em um enorme e rápido fracasso. A derrota da improvisada frota paraguaia, em 11 de junho de 1865, a destruição da coluna paraguaia na batalha de Yatay, em Pasos de los Libres, em 17 de agosto de 1865 e a rendição do exército paraguaio cercado em Uruguaiana, sem luta, em 18 de setembro de 1865, determinaram o retorno ao país dos exércitos expedicionários vergastados pelas derrotas, pela rendição e pelo enorme número de mortos por doença. A situação era tal que se cria na derrota paraguaia em poucos meses, como propusera Bartolomé Mitre no início do conflito.

Em 17 de abril de 1866, poderosas tropas aliancistas iniciaram a transposição do rio Paraná, cinco meses após o retorno do exército paraguaio derrotado ao país. A campanha defensiva diferiria profundamente da aventura ofensiva, que não teria contado com adesão decidida da população. Então, a guerra assumiu o caráter de desesperada defesa popular do território nacional, empreendida principalmente pelas amplas comunidades camponesas do país. As tropas aliancistas, sobretudo os exércitos do Império do Brasil, com quase dez milhões de habitantes, em 1872, penariam ainda por mais de quatro anos para vergar um país com talvez não mais de 450 mil habitantes.

Os últimos combates deram-se em Pirebebey, em 12 de agosto, e em Campo Grande [Acosta $\tilde{\mathrm{Nu}}$ ], em 16 de agosto de 1869, contra um exército paraguaio fantasmagórico, com armamentos em frangalhos, formado por velhos, adolescentes, crianças e alguns poucos veteranos, em geral feridos e doentes. Em $1^{\circ}$ de março de 1870, a guerra findou, em Cerro-Corá, com a morte de Francisco Solano López, a quem jamais o governo imperial concedeu espaço para rendição honrosa. Ao silêncio das armas, seguiram-se os longos anos de ocupação militar argentina e imperial, as décadas de suserania estrangeira sobre um país arrasado, humilhado e vergado por dívida de guerra impagável. Derrotadas e dizimadas, as classes camponesas foram separadas para sempre das terras que exploravam, destruindo-se a grande singularidade da formação social paraguaia.

A historiografia brasileira dedicou relativamente pouca atenção ao grande conflito de 1864-1870, por décadas um quase monopólio dos militares-historiadores do Exército. Superado o hiato e o impacto causados pela reportagem historiográfica de J. J. Chiavenato, Genocídio Americano: a guerra do Paraguai, em 1979, houve um forte retorno tendencial e refinamento epistemológico das teses e temas centrais da historiografia nacional-patriótica sobre a guerra. 
Realidade que se mantém ainda parcialmente, apesar de novo interesse sobre o conflito por parte da historiografia acadêmica brasileira, que tem produzido importantes trabalhos, sobretudo em um viés monográfico.

No Programa de Pós-Graduação em História da Universidade de Passo Fundo (UPF), que dedica ampla atenção à historiografia das nações da bacia do Prata, foram e estão sendo desenvolvidos diversos trabalhos sobre múltiplos aspectos daquele domínio, sob a responsabilidade de variados orientadores. Muitos desses trabalhos foram e estão sendo publicados.

Ao cumprirem-se os 150 anos do que é visto como o início do grande conflito, a Revista do Programa de Pós-Graduação em História da UPF retornou a tema já abordado no dossiê dedicado à "Bacia do Prata - o Paraguai" (v. 11, n. 2, jul./dez. 2011), que apresentou trabalhos dos historiadores Alberto Moby Ribeiro da Silva, Bernardo Coronel, Diego Buffa, León Pomer, Maria José Becerra, Mário Maestri, Paulo César Possamai, Sergio Guerra Vilaboy, e duas entrevistas, de Maria Victoria Baratta e Silvânia de Queiróz.

O presente dossiê, dedicado aos 150 anos do Grande Conflito da Bacia do Prata, retoma a análise de múltiplos aspectos históricos daquele sucesso, a partir de diversas visões. O dossiê divide-se em dois núcleos temáticos. No primeiro - A guerra: O Paraguai e a Argentina -, em O inimigo na trincheira: a imagem dos aliados nas páginas dos jornais brasileiros e argentinos na guerra contra o Paraguai, o historiador e jornalista Mauro César Silveira refere-se ao conflito, nem sempre surdo, entre os tradicionais inimigos, então aliados, contra o Paraguai, nos jornais daqueles países. Em Tierra, nación y construcción del Estado en el Paraguay del siglo XIX, o historiador argentino Ignácio Telesca aborda múltiplos aspectos da sociedade paraguaia antes do conflito - identidade nacional, relacionamento com a terra, construção do Estado, etc. Em Situación economica y militar de Argentina entre 1852 y el Inicio de la Guerra del Paraguay, o historiador argentino cel. Sérgio Sanchez, partindo dos anos após a queda de Juan Manuel de Rosas, aborda a difícil situação financeira da República Argentina, antes do início da guerra. Finalmente, no texto Estanislao Zeballos: a história jamais escrita da Guerra da Tríplice Aliança, Mário Maestri discute a documentação produzida sobre o conflito, em 1887-1888, por aquele político argentino e perscruta, entre outras questões, as eventuais razões de jamais ter ele produzido a prometida história geral sobre o conflito.

No segundo núcleo temático - A guerra: O Mato Grosso do Sul e o Brasil -, em A participação dos indígenas da banda meridional da Capitania de Mato Grosso na Guerra do Paraguai, Paulo Marcos Esselin e Vera Lúcia Ferreira Vargas abordam tema pouco discutido pela historiografia especializada - a participação dos nativos do sul do Mato Grosso quando da invasão paraguaia daquela região. Em 150 anos da Guerra de Paraguai: projetos, celebrações e apropriações da retirada da Laguna, Ana Paula Squinelo e Jérri Roberto Marin abordam o uso dos sucessos do conflito, com destaque para a retirada da Laguna, pelo Estado, na construção da 
identidade sul-mato-grossense. Em A vila de Corumbá e a Grande Guerra: algumas reflexões, Elaine Cancian discute sucessos sofridos por aquela aglomeração e sua população, quando do ataque e da ocupação paraguaios. Finalmente, em "Discursos, poesias, flores, bonita recepção [...] e as pensões nada!". Os acontecimentos no retorno dos voluntários da pátria, com o palco na cidade do Rio de Janeiro, Ana Beatriz R. de Souza desvela aspectos das vicissitudes do retorno dos voluntários da pátria ao Brasil após o conflito, e da muito parcial satisfação das promessas realizadas pelo Estado imperial.

Na seção Artigos Livres, apresentamos o trabalho Fronteiras fluídas: Rio Grande do Sul e a Banda Oriental no processo de fixação de limites, de Ana Luiza Setti Reckziegel, que aborda o processo de fixação dos limites entre a região do Rio Grande do Sul e a Banda Oriental durante os séculos XVI e XIX, explorando a dificuldade no seu cumprimento visto que ali se configurou uma região cuja história de interação desfazia o que a lógica estatal estabelecia. E também o artigo de Gerson Trombetta, Entre a lágrima e a transgressão: a ambiguidade do kitsch no projeto moderno da arte e da arquitetura, que analisa o fenômeno kitsch enquanto estética de "ver e possuir" e também enquanto agregador de memórias. Por fim, Silvânia de Queiroz resenha um recente livro relacionado ao conflito, apresentado inicialmente como dissertação de mestrado no PPGH-UPF.

Mário Maestri Programa de Pós-Graduação em História da UPF

Paulo Marcos Esselin Universidade Federal de Mato Grosso do Sul 


\section{Editorial}

\section{Years after the Great La Plata Conflict:Diverse Issues, Diverse Perspectives}

On August $30^{\text {th }}, 1864$, the Paraguayan government officially declared that the military intervention brought about by the Brazilian Empire upon the Republic of Uruguay was a reason for war for threatening the "balance of the states of the La Plata" and their national interests. On October $12^{\text {th }}$, a deployment of the Imperial army entered the Oriental Republic of Uruguay and assaulted the village of Mello, the administrative headquarters of the department of Cerro Largo. On October $20^{\text {th }}$, due to the secret agreement of Santa Lucia arranged by admiral Tamandaré, Venâncio Flores accepts the demands made by the Brazilian Empire that, in a few months, put an end to the Uruguayan blanco constitutional government, enthroning the colorado dictator.

The Paraguayan government had already gone nearly bankrupt as the Argentinean unitarians took the country since the battle of Pavón, on September $17^{\text {th }}, 1861$. The international trade of the Republic of Paraguay was under sursis due to the Imperial control of the port of Montevideo, with severe border pending matters with the Brazilian Empire. The interruption of international trade was a perhaps mortal attack to the Lopez order, which was grounded on the mercantile extroversion in the country, in the context of its independence and autonomy.

On November $12^{\text {th }}, 1864$, the Paraguayan government halted the Imperial packet-boat Marquês de Olinda while cruising the Paraguay river on its way to Corumbá, taking aboard colonel Frederico Carneiro de Campos, the new president of the province of Mato Grosso, thus declaring war to the Empire. On December $14^{\text {th }}$, Paraguayan military expeditions set out to take the fort of Coimbra, the south of the province of Mato Grosso, and occupy the territories being disputed by both countries. On April $13^{\text {th }}-14^{\text {th }}, 1865$, troops of that country attacked and took the village of Corrientes. On June $10^{\text {th }}-12^{\text {th }}, 1865$, an important Paraguayan military column entered Rio Grande do Sul through the village of São Borja.

Due to the Paraguayan offensive, the so-called Treaty of the Triple Alliance was urgently signed in Buenos Aires on May $1^{\text {st }}, 1865$. The diploma, which had been outlined around a year arlier, on June 1864, in Puntas del Rosário, Uruguay, defined the general conditions of the alliance between the Republic of Argentina and the Brazilian Empire to impose shared hegemony in the La Plata Basin, submitting the Republic of Uruguay and reducing Paraguay 
to a semi-tributary State. One of the terms for giving Venancio Flores the oriental government was the commitment of subaltern participation of Uruguay in the alliance against Paraguay.

The treaty ruled the maximum direction of the war, as a whole under Argentinean command; the destitution and reformulation of the government of Paraguay; the new borders of the Empire and Argentina with that country; the payment of heavy war debt; no discussion of peace until unconditional rendition, etc. Due to its despotic traits and the disrespect towards international habits and customs, the Treaty would remain unknown even to the Argentinean and Imperial parliaments. The Flores dictatorship ruled in Uruguay.

The rash offensive expedition made by the Paraguayan army ended in huge and quick defeat. The defeat of the improvised Paraguayan fleet, on June 11 ${ }^{\text {th }}, 1865$; the destruction of the Paraguayan column in the battle of Yatay, in Pasos de los Libres, on August $17^{\text {th }}, 1865$; the capitulation of the Paraguayan army under siege in Uruguaiana, with no fighting, on September $18^{\text {th }}, 1865$, led the expeditionary armies, outworn by defeats, rendition and the vast number of individuals killed by disease, to return to their country. Such was the situation leading to the Paraguayan defeat within a few months, as foreseen by Bartolomé Mitre by the beginning of the conflict.

On April $17^{\text {th }}, 1866$, powerful allied troops started crossing the Paraná river, five months after the defeated Paraguayan army returned to the country. That defensive campaign would be quite different from the offensive adventure, which had not counted with decisive support from the population. Then, the war turned into the desperate defense of the national territory by its people, carried out mostly by the country's wide peasant communities. The allied troops, particularly the armies of the Brazilian Empire, with nearly ten thousand inhabitants, in 1872 , would struggle for more than four years to subdue a country with perhaps no more than 450 thousand inhabitants.

The last combats took place in Pirebebey, on August $12^{\text {th }}$, and in Campo Grande [Acosta $\tilde{\mathrm{Nu}}$ ], on August $16^{\text {th }}, 1869$, against a ghostly Paraguayan army, with shattered armaments, made up of old men, teenagers, children and a few veterans who were usually wounded and ill. On March 1st, 1870, the war ended in Cerro-Corá, with the death of Francisco Solano López, to whom the Imperial government never gave a chance for honorable rendition. The silence of arms was followed by long years of Imperial and Argentinean military occupation, decades of foreign suzerainty upon a country that was devastated, humiliated and bound by unpayable war debt. As they were defeated and wiped out, the peasant classes were forever separated from the lands they exploited, and the great singularity of the Paraguayan social formation was destroyed.

Brazilian historiography has given relatively little attention to the great conflict of 18641870, which was utterly monopolized by military historians from the Army for decades. After the hiatus and the impact caused by J.J. Chiavenato's historiographic report, American Genocide: the Paraguay War, in 1979, there was strong tendency of return and epistemological refinement of the main themes and theses of the national-patriotic historiography about the 
war. This reality is still partially true, despite the recent interest in the conflict shown by the Brazilian academic historiography, which has produced important works, mostly from an academic bias.

Several works have been developed on multiple aspects of the theme at the Program of Post-Graduation in History at UPF, which gives wide attention to the historiography of the nations of the La Plata Basin, under the responsibility of a number of advisors. Many of these works have been and are still being published.

At the $150^{\text {th }}$ anniversary of what is regarded as the beginning of the great conflict, the Journal of the Program of Post-Graduation in History at UPF reviewed the theme that was addressed in the dossier dedicated to "The La Plata Basin - Paraguay" [v. 11, n. 2, July-Dec. 2011], which presented works by historians Alberto Moby Ribeiro da Silva, Bernardo Coronel, Diego Buffa, León Pomer, Maria José Becerra, Mário Maestri, Paulo César Possamai, Sergio Guerra Vilaboy and two interviews by Maria Victoria Baratta and Silvânia de Queiróz.

This dossier, dedicated to the " 150 years of the Great Conflict of the La Plata Basin" readdresses the analysis of multiple aspects of that historical success, from different viewpoints. The dossier is organized into two thematic units. In the first - "The War: Paraguay and Argentina" -, in "The enemy in the trench: the image of the allies on the pages of Brazilian and Argentinean newspapers in the war against Paraguay", historian and journalist Mauro César Silveira refers to the conflict, not always silent, between the traditional enemies, then allies, against Paraguay, in the newspapers of those countries. In "Land, nation and the construction of the State in 19th-century Paraguay", Argentinean historian Ignácio Telesca addresses multiple aspects of the Paraguayan society before the conflict - national identity; relationship with the land; the construction of the State, etc. In "The economical and military situation of Argentina between 1852 and the beginning of the Paraguay War", Argentinean historian col. Sérgio Sanchez, starting from the years after the fall of Juan Manuel de Rosas, addresses the difficult financial situation of the Republic of Argentina, prior to the beginning of the war. Finally, in the text "Estanislao Zeballos: the never written history of the War of the Triple Alliance", Mário Maestri discusses the documentation about the conflict produced in 18871888 by that Argentinean politician and examines, among other issues, the possible reasons why he never released the promised general history of the conflict.

In the second thematic unit- "The war: Mato Grosso do Sul and Brazil" -, in "The participation of natives from the southern part of the Captaincy of Mato Grosso in the Paraguay War", Paulo Marcos Esselin and Vera Lúcia Ferreira Vargas address a theme that has been undervalued by the specialized historiography - the participation of natives from southern Mato Grosso during the Paraguayan invasion of that region. In " $150^{\text {th }}$ anniversary of the Paraguay War: projects, celebrations and appropriation of the Withdrawal of Laguna", Ana Paula Squinelo 
and Jérri Roberto Marin address how the State used the successes of the conflict, particularly the Withdrawal of Laguna, in the construction of the identity of Mato Grosso do Sul. In "The village of Corumbá and the Great War: some reflections", Elaine Cancian, discusses the successes achieved by that agglomeration and its people, during the Paraguayan attack and occupation. Finally, in "'Speeches, poetry, flowers, beautiful reception [...] and no allowance due!'. The events on homeland's volunteers return", centered in the city of Rio de Janeiro, Ana Beatriz R. de Souza reveals aspects of the vicissitudes of the return of the volunteers of the country to Brazil, after the conflict, and the very partial fulfillment of promises made by the Imperial State.

In Articles Free section, we present the work "Fluid boundaries: the RS and the Banda Oriental in the process of setting limits", Ana Luiza Setti Reckziegel which addresses the process fixing the boundaries between the region of Rio Grande do southern and Eastern Band during the sixteenth and nineteenth centuries, exploring the difficulty in complying with it since there is set a region whose interaction history undid what the state logic established. The article Gerson Trombetta, "Between tears and transgression: the ambiguity of kitsch in modern art and architecture design", analyzes the phenomenon as kitsch aesthetic of "see and have" as well as aggregator memories. Silvânia de Queiroz review a recently-published book related to the conflict, first presented as master's dissertations at the Program of Post-Graduation in History at UPF.

Mário Maestri Program of Post-Graduation at the University of Passo Fundo (PPGH-UPF) Paulo Marcos Esselin Federal University of Mato Grosso do Sul (UFMS) 


\section{Editorial}

\section{Desde 150 Años del Gran Conflicto del Plata: Muchas Cuestiones, Muchos 0jeares}

El 30 de agosto de 1864, el gobierno paraguayo afirmó solemne que la intervención militar del Imperio de Brasil en la República del Uruguay sería la razón de guerra, al atacar el "equilibrio de los estados del Plata" y sus intereses nacionales. El 12 de octubre, desapego del ejército imperial entraba en a República Oriental del Uruguay y asaltaba la villa de Mello, sede administrativa del departamento de Cerro Largo. El 20 de octubre, con el acuerdo secreto de Santa Lucia hecho por el almirante Tamandaré, Venancio Flores acepta las exigencias del Imperio de Brasil que, en unos pocos meses, acabó con el gobierno constitucional blanco uruguayo, entronizando el dictador colorado.

El gobierno paraguayo estaba con los platos casi todos rotos con los unitarios porteños que dominaban el país desde la batalla de Pavón, el 17 de septiembre de 1861. El control imperial del puerto de Montevideo ponía bajo libertad condicional el comercio internacional de la República del Paraguay, con graves pendencias de la frontera con el Imperio de Brasil. La interrupción del comercio internacional establecería el golpe tal vez de muerte al orden lopista, apoyado en la extroversión mercantil del país, en el contexto de su independencia y autonomía.

El 12 de noviembre de 1864, el gobierno paraguayo detuvo el paquete imperial Marqués de Olinda, en viaje al río Paraguay, para Corumbá, teniendo a bordo en nuevo presidente de la provincia de Mato Grosso, coronel Frederico Carneiro de Campos, declarando guerra al Imperio en la misma ocasión. El 14 de diciembre, salían expediciones militares paraguayas para asaltar el fuerte de Coimbra, el sur de la provincia de Mato Grosso y ocupar los territorios en litigio entre los dos países. El 13-14 de abril de 1865, tropas de aquella nación atacaron y ocuparon la villa de Corrientes. El 10-12 de junio de 1865, importante columna militar paraguaya entraba en el Rio Grande do Sul por la villa de São Borja.

Con la ofensiva paraguaya, fue firmado, rápidamente, el $1^{\circ}$. de mayo de 1865 , el nombrado Tratado de la Triple Alianza, en Buenos Aires. Ya tratado meses antes, en junio de 1864, en Puntas del Rosario, en Uruguay, el diploma definía las condiciones generales de la alianza entre la República Argentina y el Imperio de Brasil para que impusiesen la hegemonía compartida en el Plata, presentando la República del Uruguay y reduciendo el Paraguay a Estado 
semitributario. En las condiciones de entrega del gobierno oriental a Venancio Flores estaba el compromiso de participación subalterno del Uruguay en la alianza contra el Paraguay.

El tratado regia la dirección máxima de la guerra, en general bajo comando argentino; la destitución y reformulación del gobierno del Paraguay; las nuevas fronteras del Imperio y de Argentina con aquel país; el pago de la pesada deuda de guerra; ninguna discusión de paz hasta la rendición incondicional, etcétera. Debido su carácter despótico y la falta de respeto a los hábitos y costumbres internacionales, el Tratado sería mantenido en secreto de los propios parlamentos argentino e imperial. En Uruguay, reinaba la dictadura florista.

El error de la expedición ofensiva del ejército paraguayo resultó en un gran y rápido fracaso. La derrota de la improvisada flota paraguaya, el 11 de junio de 1865; la destrucción de la columna paraguaya en la batalla de Yatay, en Pasos de los Libres, el 17 de agosto de 1865; la rendición del ejército paraguayo cercado en Uruguaiana, sin lucha, el 18 de septiembre de 1865, determinó la vuelta al país de los ejércitos expedicionarios castigados por la derrotas, por la rendición y por el gran número de muertos a causa de enfermedades. La situación era tal que se creía en la derrota paraguaya en pocos meses, como proponía Bartolomé Mitre en el inicio del conflicto.

El 17 de abril de 1866, poderosas tropas aliancistas empezaron la trasposición del río Paraná, cinco meses tras la vuelta del ejército paraguayo derrotado al país. La campaña defensiva era distinta de la aventura ofensiva, pues no podría contar con la adhesión de la población. Entonces, la guerra asumió el carácter de desesperada defensa popular del territorio nacional, emprendida, sobre todo, por las amplias comunidades campesinas del país. Las tropas en alianza, sobre todo los ejércitos del Imperio de Brasil, con aproximadamente diez millones de habitantes, en 1872, sufrirían aún más de cuatro años para tener un país con tal vez no más de 450 mil habitantes.

Las últimas luchas se dieron en Pirebebey, el 12 de agosto, y en Campo Grande [Acosta Nul], el 16 de agosto de 1869, contra un ejército paraguayo fantasmagórico, con armas andrajos, formado por viejos, adolescentes, niños y algunos pocos veteranos, en general heridos y enfermos. El 1․ de marzo de 1870, la guerra terminó, en Cerro-Coará, con la muerte de Francisco Solano López, quien jamás el gobierno imperial concedió espacio para rendición honorable. En el silencio de las armas se siguieron muchos años de ocupación militar argentina e imperial, las décadas de soberanía extranjera sobre país afligido, humillado y retorcido por la deuda de la guerra impagable. Derrotadas y acabadas, las clases campesinas fueron separadas para siempre de la tierra que exploraron, destruyendo la gran singularidad de la formación social paraguaya.

La historiografía brasileña dedicó poca atención al gran conflicto de 1864-1870, durante décadas casi un monopolio de militares-historiadores del Ejército. Superado el hiato y el impacto ocasionados por el reportaje historiográfico de J. J. Chiavenato, Genocidio Americano: la guerra del Paraguay, en 1979, hubo un fuerte retorno de tendencia y refinamiento epistemológico de las tesinas y temáticas centrales de la historiografía nacional-patriótica acerca de la 
guerra. Realidad que se mantiene aún parcialmente, aunque tengan nuevos intereses sobre el conflicto por parte de la historiografía académica brasileña, que tiene producido importantes trabajos, sobre todo en un sesgo monográfico.

En el Programa de Postgrado en Historia de la UPF, que dedica amplia atención a la historiografía de las naciones de la cuenca del Plata, fueron y son desarrollados varios trabajos sobre múltiples aspectos acerca de aquel dominio, bajo la responsabilidad de diferentes orientadores. Muchos de los trabajos fueron y son publicados.

Cuando se cumplen 150 años de lo que es visto como inicio del gran conflicto, la Revista del Programa de Postgrado en Historia de la UPF vuelve a la temática ya trabajada en el dosier dedicado a la "Cuenca del Plata" - el Paraguay [v.11, n. 2, jul.-dic. 2011], que presentó trabajos de los historiadores Alberto Moby Ribeiro da Silva, Bernardo Coronel, Diego Buffa, León Pomer, Maria José Becerra, Mário Maestri, Paulo César Possamai, Sergio Guerra Vilaboy y dos entrevistas, de Maria Victoria Baratta y Silvânia de Queiróz.

Este dosier, dedicado a los "150 años del Gran Conflicto de la Cuenca del Plata" vuelve al análisis de múltiples aspectos de aquel suceso histórico, desde muchas visiones. El dosier se divide en dos núcleos temáticos. En el primero - "La guerra: El Pataguay y la Argentina"-, en "El enemigo en la zanja: la imagen de los aliados en las páginas de los periódicos brasileños y argentinos en la guerra contra el Paraguay", el historiador y periodista Mauro César Silveira se refiere al conflicto, ni siempre sordo, entre los tradicionales enemigos, entonces aliados, contra el Paraguay, en los periódicos de aquel país. En “Tierra, nación y construcción del Estado en el Paraguay del siglo XIX", el historiador argentino Ignácio Telesca trata de múltiples aspectos de la sociedad paraguaya antes del conflicto - identidad nacional; trato con la tierra; construcción del Estado, etcétera. En la "Situación económica y militar de Argentina entre 1852 y el Inicio de la Guerra del Paraguay", el historiador argentino coronel Sérgio Sanchez, partiendo dos años tras la caída de Juan Manuel de Rosas, abarca la difícil situación financiera de la República Argentina, antes del inicio de la guerra. Para cerrar, en el texto “Estanislao Zeballos: La historia jamás escrita de la Guerra de la Triple Alianza”, Mário Maestri discute la documentación acerca del conflicto producida, en 1887-1888, por aquel político argentino y compañeros, entre otras cuestiones, las eventuales razones de jamás él tener producido la prometida historia general sobre el conflicto.

En el según núcleo temático - "La guerra: El Mato Grosso do Sul y el Brasil”-, en "La participación de indígenas del grupo meridional de la Capitanía de Mato Grosso en la Guerra del Paraguay", Paulo Marcos Esselin y Vera Lúcia Ferreira Vargas tratan de una temática poco discutida por la historiografía especializada - la participación de nativos del sur de Mato Grosso cuando ocurrió la invasión paraguaya en aquella región. En “150 aniversario de la Guerra de Paraguay: proyectos, celebraciones y apropiaciones de la Retirada de la Laguna", Ana Paula 
Squinelo y Jérri Roberto Marin abarcan el uso de los éxitos del conflicto, con énfasis para la Retirada de la Laguna, por el Estado, en la construcción de identidad sur-mato-grosense. En "La villa de Corumbá y la Gran Guerra: algunas reflexiones", Elaine Cancian, discute sucesos ocurridos por aquella aglomeración y su población, cuando ocurrido el ataque y ocupación paraguaya. Para terminar, en "'Discursos, poesías, flores, hermosa recepción [...] iy las pensiones nada!'. Los eventos en el retorno de los voluntarios de la patria", con el palco en la ciudad de Rio de Janeiro, Ana Beatriz R. de Souza revela aspectos de las vicisitudes del retorno de los voluntarios de la patria a Brasil, tras el conflicto, y de la parcial satisfacción de las promesas realizadas por el Estado imperial.

En los artículos sección libre, presentamos la obra "Fronteras fluidas: la RS y la Banda Oriental en el proceso de fijación de límites", Ana Luiza Setti Reckziegel que aborda el proceso de fijación de los límites entre la región de Río Grande Sur y la Banda Oriental durante los siglos XVI y XIX, la exploración de la dificultad de cumplir con ella ya que no se establece una región cuya historia interacción deshizo lo que la lógica estatal establecida. El artículo Gerson Trombetta, "Entre lágrimas y transgresión: la ambigüedad del kitsch en el arte moderno y el diseño de la arquitectura", analiza el fenómeno como kitsch estética de "ver y tener", así como recuerdos agregador. Silvânia de Queiroz reseña un reciente libro relacionado al conflicto, presentado al principio como disertación de máster en el Programa de Postgrado en Historia de la UPF.

Mário Maestri PPGH-UPF

Paulo Marcos Esselin

UFMS 